\title{
The International Human Rights Regime: Still Part of the Problem?
}

\section{Citation}

David W. Kennedy, 2012. The International Human Rights Regime: Still Part of the Problem? In Examining Critical Perspective on Human Rights, ed. Rob Dickinson, Elena Katselli, Colin Murray, Ole W. Pedersen: 19-34. Cambridge, UK: Cambridge University Press.

\section{Permanent link}

http://nrs.harvard.edu/urn-3:HUL.InstRepos:15749103

\section{Terms of Use}

This article was downloaded from Harvard University's DASH repository, and is made available under the terms and conditions applicable to Other Posted Material, as set forth at http:// nrs.harvard.edu/urn-3:HUL.InstRepos:dash.current.terms-of-use\#LAA

\section{Share Your Story}

The Harvard community has made this article openly available.

Please share how this access benefits you. Submit a story.

Accessibility 


\title{
The international human rights regime: still part of the problem?
}

\author{
DAVID KENNEDY
}

Let me begin by expressing my gratitude to the editors of this volume, and to the University of Newcastle, for organizing the conversation from which these papers were developed. I was tremendously honored that colleagues would find my short essay on the human rights movement, first published a decade ago, still worthy of discussion. ${ }^{1}$ I should start by emphasizing that more than sixty years after the adoption of the Universal Declaration of Human Rights there is much to celebrate. Human rights is no longer only an idea. Over the last half century, we have amassed an enormous library of legal norms and aspirational declarations. A complex institutional practice has grown up in the shadow of those pronouncements to promote, defend, interpret, elaborate, implement, enforce, and simply to honor them. There is no question the human rights movement has done a great deal of good, freeing individuals from great harm, and raising the standards by which governments are judged. It has cast light on catastrophic conditions in prisons around the world. Human rights advocacy became at once a professional practice and a movement.

It would be hard to date, but sometime not too long ago, human rights also became a practice of governance. Institutionally, it would be more accurate today to speak of international human rights as a 'regime' than as a movement or an idea. Governments have human rights departments, ombudsmen, special rapporteurs, and investigative divisions. If you are a diplomat, you can be assigned human rights as a specialty. If you are a law student, you can aspire to a career in the field of human rights. We have human rights networks, human rights courts,

'D. Kennedy, 'The international human rights movement: part of the problem?' European Human Rights Law Review 3 (2001) 245-67, reprinted in Harvard Human Rights Journal 14 (2002) 101-26. 
non-governmental organizations, citizens' initiatives, government bureaus, international institutions, private foundations, military staffs, specialized journalists, authors, and media - all in one or another way 'doing' human rights. Diplomats denounce one another, citizens write letters and send checks, and a cadre of diverse professionals travels the world denouncing governments and promoting human rights.

Humanitarian voices are increasingly powerful on the international stage - often providing the terms through which global power is exercised, wars planned and fought. Human rights has elbowed economics aside in our development agencies, which now spend billions once allocated to dams and roadways on court reform, judicial training, and 'rule of law' injection. The UN High Commissioner for Refugees designs and manages asylum and immigration policies with governments around the world. And of course, human rights has also become an academic specialty - in law faculties, but also in departments of sociology, psychology, philosophy, political science, public health, and more. Some scholars go further, proclaiming ours the age of human rights. In this view, human rights has become more than an institutional regime it is now a universal ideology, an international standard of legitimacy for sovereign power, a common vernacular of justice for a global civil society. Such an altered consciousness for the world's elites has long been among the movement's most fervent dreams. On this score, I am less sure, although it is certainly true that all manner of political maneuvers and strategies are now pursued in the rhetoric of human rights and the awareness of human rights violations now does seem to call forth - or delegitimate - political action.

There is no doubt that this is all a real achievement. At the same time, however, the discussions in Newcastle from which this volume has emerged took place at a moment of chastening for the human rights profession. Both beginners and seasoned veterans are far more savvy and pragmatic than any of us were when I started in the field almost thirty years ago. Painful lessons hard-learned have sown nagging doubts. There are so many unsavory things one simply cannot do anything about, so many unsavory things one finds oneself doing in the human rights business.

It is interesting how often we trace the origins of human rights to a declaration and locate the origins of the movement in a group of texts adopted after the Second World War. Human rights in the world is not a text. As a form of governance, a profession, a movement, a universal ideological practice, human rights was launched much later, in the late 1970 s and early 1980s, just as the pendulum swung for a generation 
toward Thatcher, Reagan, and the politics of 'neo-liberalism.' I believe I taught a course on human rights at Harvard for the first time in 1982, and made my first human rights junket the next year, to visit prisons in Israel. The following year I was in Latin America, prisons again. By 1984, I was in Geneva working for the UN. In the heyday of human rights, it all seemed much simpler - we were turning text into deed, aspiration into institution. The language of human rights was everywhere, while the limits of what it could accomplish were only barely apparent.

Who were the first human rights professionals? Some had been liberals of the 1960s, taking their civil liberties commitments onto the global stage. Others, like myself, were children of the 1970s for whom Jimmy Carter had made human rights a respectable vernacular for transposing what we remembered of sixties idealism to international affairs. I know my academic colleagues felt we were redeeming the better promise of Carter's diplomacy, turning the Cold War struggle from proxy wars to direct affirmation of democracy and citizens' rights. Russian dissidents and their Western supporters were big players.

Over the next ten years, it seemed that democracy was on the rise and that we had ringside seats. I remember observing a trial in Prague on a grey and rainy October Tuesday in 1989, in a small dilapidated courthouse on the outskirts of town, only to return the following May, flowers in bloom, for a meeting of Harvard Law School's European alumni in a newly poshed-up hotel. I asked where to find the defendant whose trial I had sat through - a member of a John Lennon peace group - and was directed to 'the Castle.' It seems that, after the Velvet Revolution, he had gone to work in Václav Havel's office, where he was far too busy for an appointment. It was exciting stuff. After 1989, the human rights and humanitarian agendas benefited from an enormous burst of energy and self-confidence. On a recent visit, I was surprised to find that Human Rights Watch now takes up several floors in the Empire State Building, naming and shaming from a great height.

At the same time, since the early 1980s we have all learned a great deal about the dilemmas, dark sides, and disappointments of human rights as a tool for global governance. A surprising number of foot soldiers have left their jobs and written up their stories, stories of early faith confounded, lost amid the vagaries of politics and context and all the duplicities of good intentions brought to faraway places. Human rights today is at once more powerful and less innocent, urgent, compelling. It is hard to say why, or how this chastening has come about. Perhaps the movement bit off more than it could chew. 
There were certainly many disappointments. So many interventions did not work out as we had planned. We learned that human rights can also legitimate a regime, even a regime we believe violates rights, if only by isolating the violation in a way which normalizes the rest of the regime's activities. As an absolute language of righteousness and moral aspiration came to be used strategically, human rights became less compelling, easy to interpret as nothing but strategy, cover for political objectives, particular interests clothing themselves in the language of the universal.

That human rights advocates and practitioners are no longer as naïve as we once were is itself worthy of celebration. Modern human rights professionals are often the first to know and to admit the limits of their language, their institutional practices, their governance routines. They know there are darker sides, they weigh and balance and think shrewdly and practically.

This, it seems to me, is the real promise of volumes like this one. Serious academic inquiry will also be critical inquiry, illuminating what has gone awry as well as what has been achieved. The human rights movement is up to it - indeed, it needs precisely this kind of serious interdisciplinary scrutiny.

Of course, the profession has also developed routine practices to disperse the nausea and still the confusion which go with human rights activism. They are careful to separate their public piety and their private cynicism, the pragmatism of the field and the earnestness of headquarters, the rhetoric of public relations and the reality of recruiting all those victims and gathering all that testimony, lest mixing the one with the other damage the endeavor or discourage the donors. We should bring these mechanisms into focus, for they permit knowledge of the dark side to remain as readily denied as admitted. In the field, it is denied in the name of the pragmatic, at headquarters in the name of ethical commitment.

I attribute the experience of chastening and disenchantment to increasing awareness of two related dangers of human rights work. First, the tendency of human rights idealism to veer toward idolatry, enchanting the tools and norms and practitioners of human rights, while remaining marginal to power, standing on the sidelines 'speaking truth.' For this, the traditional remedy is pragmatism. The activist practice of human rights should become more pragmatic.

Second, the pitfalls of pragmatism, of participation in governance, with all the tools of policy analysis, instrumental reason, and savvy evaluation 
of the costs and benefits of human rights initiatives that entails. For this, the traditional remedy is a return to ethics - and the dangers of idolatry.

There is no recipe or institutional roadmap to avoid these parallel difficulties, unfortunately. My worry is that, together, they chill the appetite for political decision, promoting the knowing routines of professional advocacy over the exercise of discretion and the experience of responsibility. What I do think we can hope for is a kind of professional, political, and moral vigilance, discipline, and renewal: a posture for the humanitarian professional which is neither ethically nor instrumentally self-confident, yet prepared to accept responsibility for the damage his or her initiatives will cause.

These twin difficulties - of idolatry and pragmatism - are not unique to human rights. They are common to many international humanist and humanitarian governance projects. Assessing - or celebrating - humanist governance requires that we focus on humanism as a political project: commitments that are widely shared and that have been transformed over the last thirty or forty years into concrete legal regimes and policy initiatives. In this light, we ought not to see humanism against power, talking to power, advising power, restraining power, but humanism as power; not humanism as the modest handmaiden of force, but humanism as the motive and method of force; humanism, moreover, as a professional experience. The experience of ruling - or perhaps, more modestly sometimes, of not ruling, of advising rulership - in the name of an appealing grab bag of ethical commitments.

Like any other attractive, professional self-image, the experience of ruling the world in the name of laudable commitments must be sustained. And yet tensions among humanist commitments - engage the world, but in the name of a cosmopolitan tolerance; reform the world, while renouncing the tools of power politics; rule the world, but live in an international community of modest humanist consensus - have gotten built into the legal and institutional tools we have constructed to give them expression. These tensions have left us ambivalent about rulership. And ambivalent rulership is often rulership denied. We sustain the experience of humanism by denying ourselves the experience of our own rulership. We prefer to think of ourselves off to one side, speaking truth to power - or hidden in the policy apparatus advising other peoplethe princes - to humanize their work. I suspect that the difficulties we encounter with humanist idealism and pragmatism arise from a reluctance to acknowledge the extent to which humanitarians have become rulers. Humanist rulers are chastened and disenchanted humanists. 
They are unsettled at having become participants, rather than observers and critics, of global governance. To my mind, before they can become self-confident, empowered, and responsible partners in governance, humanitarians will need to learn to take responsibility for the costs as well as the benefits of their work.

\section{Idealism and the problems of idolatry}

The dangers of idolatrous rulership are well known. We are right to be worried when idealism takes over. Idealism becomes idolatry when it rules in the name of unambiguous virtue; when it overestimates the singularity of its vision and refuses to place the costs of its rulership centre-stage where they can be assessed and either refuted or taken into account. Human rights professionals know how this can happen - how they can get carried away by the human rights promise and lose sight of other virtues and other viewpoints.

It is nothing new to point out how narrowly the human rights tradition views human emancipation - focusing on what governments do to individuals, on participatory rather than economic or distributive issues, on legal, rather than social, religious, or other remedies. Problems which are hard to formulate as rights claims for individuals - collective problems, economic problems, problems of poverty or health - are easy to overlook. Emancipating people as rights holders, moreover, stresses their individual claims, their personal relationship with the state. This can encourage a politics of queue jumping among the disadvantaged, propagating attitudes of victimization and entitlement, while making cross-alliances and solutions which involve compromise and sharing more difficult.

As human rights activists, we know our profession can induce ethical deformations of various kinds. As we learn we can touch the barbaric and return unscathed, we discover there can be something voyeuristic in our gaze. We are often troubled when we acknowledge the suffering of others without abandoning our commitment to the system that produces it. We do worry that human rights so often legitimates and excuses government behaviour - setting standards below which mischief seems legitimate. We know it can be easy to sign a treaty - and then do what you want. But even compliance may do more harm than good - a wellimplemented ban on the death penalty, for example, can easily leave the general conditions of incarceration unremarked, can make life-withoutparole more legitimate, more difficult to challenge. The discourse of 
human rights speaks about torture and imprisonment and violence in a peculiar doubled way - and we worry when we come to think that way ourselves: on one hand, denunciation - somewhere a human right has been violated; but on the other, a balance - this right against that, these victims against those. We balance rights to free movement against rights of religious expression or speech. We balance security against freedom. And somehow the aura of the ethically absolute which accompanied our denunciation becomes affixed to whatever accommodative balance we strike, just as the right holders whose claims we balance come to seem equivalent, commutable, equally legitimate. Ripped from context, abstracted into rights to be balanced, the occupier and the occupied, the saviour and the sinner, can seem strangely similar.

I have repeatedly been surprised by the difficulty human rights lawyers have in acknowledging that there is law on the other side. When we invoke human rights against state power, we are pounding not only on the door of politics, but also on sovereign privilege and constitutional right. Yet we persist in thinking of inhumanity as a 'violation,' a barbarity, a lapse; as the exception, the extraconstitutional, the deviation; Guantánamo a black hole in the fabric of law - rather than one of the most intensely legalized spaces on the planet.

Human rights is all about focus - shining a light on this or that. With focus comes a common tip of the iceberg problem - focus on the real problems of refugees can make it more difficult to contest the closure of borders to economic migration. Indeed, the legal definition of 'refugee' has done as much to exclude people in grave need from protection as it has to legitimate UN engagement. After all, sexually humiliating, even torturing and killing prisoners is not the worst or most shocking thing the coalition has done in Iraq. Our horror at photos of 'human rights abuses' may also be a way of not thinking about other injuries, deaths, and mutilations the war has wrought.

By defining justice as a relationship to the state, rather than a condition in society, human rights can distract our attention from background norms and economic conditions which often do far more damage. Perhaps most disturbingly, the international human rights movement often acts as if it knows what justice means, always and for everyone -all you need to do is adopt, implement, interpret these rights. But justice is not like that. It must be built by people each time, struggled for, imagined in new ways. The most revered texts in the human rights canon are vague and open to interpretation. As a result, it is unlikely that any articulation of a global normative consensus will escape being 
perceived by those who disagree - and people will disagree - as partial, subjective, selective. These are the wages of speaking universally in a plural world.

Indeed, the crisis in confidence that crashed on the UN Human Rights Commission in recent years was not about only the appalling human rights record of governments that have served on the Commission. It also reflected the limits of turning the articulation and development of human rights over to governments in the first place. That governments would want to judge one another, to chastise their enemies and praise their friends, in a widely shared ethical vocabulary is not surprising. What is surprising is that the human rights community has been so enthusiastic about their taking up the task. The limits of a diplomatic ethics parallel the limits of any established church in a plural society: not good for the government, not good for the church.

We know we should worry that human rights (given its origins, its spokesmen, its preoccupations) has so often been a vocabulary of the center against the periphery, a vehicle for, rather than an antidote to empire. There are, moreover, real dangers to universal normative entrepreneurialism. Expressing the ethical conviction of the international community can suggest that there is, in fact, an international community' ready to stand behind one's pronouncements. It can lead people to intervene, multilaterally or otherwise, where there is no stamina, in fact, to follow through. It can suggest that those who disagree with this eliteand many do - are somehow outside the circuit of 'civilization.' Indeed, the ethical challenge for the next period will be to dissolve the hubris of a universal ethics, and to communicate modestly across ethical divisions, heightening our sense for the plural and heterogenous moral possibilities within the West, the rest, the center, the periphery.

These are all well-known worries. But they are terribly difficult to take into account - to weigh and balance against the real upsides of human rights work. It is easy for good-hearted people, humanitarians in the best senses, to get carried away with human rights. It can be all too easy to say 'let us at least begin' - let us light the first candle. Normally, of course, such an attitude in government would be completely irresponsible. Imagine a proposed road work - before the government builds the first mile, we expect them to have looked into the costs as well as the benefits. I have often spoken with human rights advocates who are proud of one or another of the movement's real achievements, but when you ask them 'what costs were associated with that success?' they rarely have a workedout response - it is as if human rights improvements had no costs. 
This kind of magical thinking should raise a red flag. We should be on guard when someone seeks to recruit us to a project that only has upsides. This is what it means for the exercise of power to fall victim to idolatry. The most significant challenges for the human rights movement in the years ahead will be to understand what it means to be a participant in governance, and not just a critic of it.

\section{Pragmatism and the perils of humanist violence}

To recount the pitfalls of idolatrous rulership is to call for the cool eyes and unsentimental calculations of a more pragmatic governance. There is something thrilling about learning to speak the practical language of policy if you think of yourself as a humanitarian - perhaps to leave the nostrums of human rights advocacy behind for a more nuanced engagement with the practical problems of rulership, with balancing harms, assessing benefits. Alongside enthusiasm for human rights as a rhetoric of global governance has grown a parallel, and equally promising rhetoric of practical wisdom about how one might bend the prince to humanist ends. The promise of this more practical humanism is nowhere better illustrated than in the modern laws of war and force, which (interestingly enough) have begun to merge with human rights as a vernacular for judging violence on the battlefield. Here also there has been enthusiasm and rapid development of norms and institutions and professional routines - and here also there has been a chastening.

We might say that the modern law of force represents a triumph for grasping the nettle of costs and benefits and infiltrating the background decision-making of those it would bend to humanitarian ends. Modern war is a legal institution. Once a bit player in military conflict, law now shapes the institutional, logistical, and physical landscape of war - and even more so for occupation. Law and human rights have infiltrated the military profession, and become - for parties on all sides of even the most asymmetric confrontations - a political and ethical vocabulary for marking legitimate power and justifiable death. Indeed, as law became an ever more important yardstick for legitimacy, legal categories became far too spongy to permit clear resolution of the most important questions - or became spongy enough to undergird the experience of self-confident outrage by parties on all sides of a conflict.

The triumph of humanist pragmatism opens opportunities and dangers. When things go well, law can provide a framework for talking across cultures about the justice and efficacy of wartime violence. At the 
same time, modern law is itself pragmatic - and surprisingly fluid. International law is no longer an affair of clear rules and sharp distinctions. Law today rarely speaks clearly, or with a single voice. As a result, the modern partnership of war and law often leaves all parties feeling their cause is just and no one feeling responsible for the deaths and suffering of war. Good legal arguments can make people lose their moral compass and sense of responsibility for the violence of war.

Just as we celebrate sixty years of human rights, we can be proud that modern war is a legal institution, not least because it has become a professional practice. Today's military is linked to the nation's commercial life, integrated with civilian and peacetime governmental institutions, and covered by the same national and international media. Officers discipline their force and organize their operations with rules. Operating across dozens of jurisdictions, today's military must also comply with innumerable local, national, and international rules regulating the use of territory, the mobilization of men, the financing of arms and logistics, and the deployment of force. If you want to screen banking data in Belgium, or hire operatives in Pakistan, or refuel your plane in Kazakhstan, you need to know the law of the place.

Law is perhaps most visibly part of military life when it privileges the killing and destruction of battle. If you kill this way, and not that, here and not there, these people and not those - what you do is privileged. If not, it is criminal. Moreover, if war remains, as Clausewitz taught us, the continuation of politics by other means, the politics continued by warfare today has itself been legalized. Political leaders act in the shadow of a knowledgeable, demanding, engaged, and institutionally entrenched national and global elite. Law has become the common vernacular of this dispersed elite, even as they argue about just what the law permits and forbids. This is what led opponents of the Iraq conflict - or Guantánamo - so often to frame their opposition in legal terms - what you are doing is illegal.

To grasp the dark sides of humanist pragmatism, we must understand two aspects of modern law: its antiformalism and its pluralism. Two hundred years ago, international law was rooted in ethics - to think about the law of war was to meditate on considerations of 'right' reason and natural justice. The call to professionalism - coinciding with the establishment of the ICRC - disengaged law from morality. One hundred years ago, law had become far more a matter of formal rules, delinked from morality and rooted in sovereign will. Law stood outside the institutions it regulated, offering a framework of sharp distinctions 
and formal boundaries. War and peace were legally distinct, separated by a formal 'declaration of war.' But ethical absolutes, let loose on matters of war and peace, can be dangerous - and seemed out of touch with an evolving practice of warfare. What was needed was something more practical - and antiformal.

We needed to translate our ethical worries into a workable wartime vernacular - not a series of idolatrous pronouncements. The International Committee of the Red Cross was again in the forefront, priding itself on its pragmatic relationship with military professionals. First, ICRC lawyers worked with the military to codify rules the military could live with - wanted to live with: no exploding bullets, respect for ambulances and medical personnel, and so forth. Of course, reliance on military acquiescence limited what could be achieved. Narrowly drawn rules permit a great deal - and legitimate what is permitted. Recognition of these costs encouraged a turn to principles and standards. Since at least 1945 , a vocabulary of principles has grown up alongside tough-minded military bargains over weaponry. The detailed rules of The Hague or Geneva have morphed into standards - simple ideas which can be printed on a wallet-sized card and taught to soldiers in the field. 'The means of war are not unlimited, each use of force must be necessary and proportional' - these have become ethical baselines for a universal modern civilization. This move to principles has allowed the law in war to infiltrate the vocabulary of the military profession while blending smoothly with human rights.

As a framework for debate and judgment, this new law in war embraces the unavoidability of trade-offs, of balancing harms, of accepting costs to achieve benefit - an experience common to both military strategists and humanitarians. At the same time, the sharp distinction between war and peace, the need for a 'declaration,' even the legal status of 'neutrality' were abandoned. The UN Charter replaces the word 'war' with more nuanced - and vague - terms like 'intervention,' 'threats to the peace,' or the 'use of armed force,' which trigger one or another institutional response. In the process, the modern law of armed conflict became a confusing mix of principles and counterprinciples, of firm rules and loose exceptions. Once-firm distinctions now melt into air when we press on them too firmly. Once 'war' itself becomes 'self-defense,' 'hostilities,' 'the use of force,' 'resort to arms,' 'police action,' 'peace enforcement,' 'peace making,' 'peacekeeping,' it becomes hard to keep it all straight. 
Indeed, law now offers the rhetorical - and doctrinal - tools to make and unmake the distinction between war and peace, allowing the boundaries of war to be managed strategically. Take the difficult question when does war end? The answer is not to be found in law or fact - but in strategy. Declaring the end of hostilities might be a matter of election theatre or military assessment. Just like announcing that there remains 'a long way to go,' or that the 'insurgency is in its final throes.' We should understand these statements as arguments. As messages - but also as weapons. Law - legal categorization - is a communication tool, and communicating the war is fighting the war. This is a war, this is an occupation, this is a police action, this is a security zone. These are insurgents, those are criminals, these are illegal combatants, and so on. All these are claims with audiences, made for a reason. Increasingly, defining the battlefield is not only a matter of deployed force - it is also a rhetorical and legal claim.

Law provides a vernacular for making such claims about a battlespace in which all these things are mixed up together. In the confusion, we want to insist on a bright line. For the military, after all, defining the battlefield defines the privilege to kill. But aid agencies also want the guys digging the wells to be seen as humanitarians, not post-conflict combatants - privileged not to be killed. Defining the not-battlefield opens a 'space' for humanitarian action.

When we use the law strategically, we change it. Moreover, strange as it may seem, there is now more than one law of armed conflict. Different nations - even in the same coalition - will have signed different treaties. The same standards look different if you anticipate battle against a technologically superior foe - or live in a Palestinian refugee camp in Gaza. Although we might disagree with one or the other interpretation, we must recognize that the legal materials are elastic enough to enable diverse interpretations. As a lawyer, advising the military about the law of war means making a prediction about how people with the power to influence our success will interpret the legitimacy of our plans.

It is easy to understand the virtues of a powerful legal vocabulary, shared by elites around the world, for judging the violence of warfare. It is exciting to see law and human rights become the mark of legitimacy as legitimacy has become the currency of power. It is more difficult to see the opportunities this opens for the military professional to harness law as a weapon, or to understand the dark sides of war by law. The American military have coined a word for this: 'Lawfare' - law as a weapon, law as a tactical ally, law as a strategic asset, an instrument of 
war. We might also think of human rights-fare: human rights as strategic asset and instrument of war.

This will take some getting used to. How should we feel when the military 'legally conditions the battlefield' by informing the public that they are entitled to kill civilians, or when our political leadership justifies warfare in the language of human rights? What is difficult for us to realize is that a war machine which used law more strategically might, in fact, be far more violent, more powerful, more ... well, legitimate. We need to remember what it means to say that compliance with international law 'legitimates.' It means, of course, that killing, maiming, humiliating, wounding people is legally privileged, authorized, permitted, and justified. And it is here that we can begin to see the darker side of humanitarian pragmatism.

The modern law of force has legitimated a great deal of warfare. Indeed, it is hard to think of a use of force that could not be legitimated in the language of the UN Charter. It is a rare statesman who launches a war simply to be aggressive. There is almost always something else to be said the province is actually ours, our rights have been violated, our enemy is not, in fact, a state, we were invited to help, they were about to attack us, we are promoting the purposes and principles of the United Nations. Something. A parallel process has eroded the firewall between civilian and military targets - it is but a short step to what the military terms 'effectsbased targeting.' And why shouldn't military operations be judged by their effects, rather than by their adherence to narrow rules that might well have all manner of perverse and unpredictable outcomes? The pragmatic assessment of wartime violence can be deeply disturbing.

Take civilian casualties. Of course, civilians will be killed in war. Limiting civilian death has become a pragmatic commitment - no unnecessary damage, not one more civilian than necessary. All we need to do is figure out just what is necessary. It is in this spirit that targets in the recent Iraq conflict were pored over by lawyers; and later, that those same lawyers, with a somewhat different strategy in view, pored over targets in Afghanistan, constantly revising the 'rules of engagement' to reflect the perceived strategic value of civilian life. We should not be surprised to hear that Human Rights Watch recently beefed up its ability to bring human rights to bear on the American practice of warfare - by hiring the man who had assessed the proportionality of American targeting for the Pentagon to do the same exercise for Human Rights Watch. Humanist pragmatism has become a partnership, within and without the government. 
At the same time, the legitimacy of wartime violence is all mixed up with the legitimacy of the war itself. It is in this atmosphere that discipline has broken down in every asymmetric struggle, when neither clear rules nor broad standards of judgment seem adequate to moor one's ethical sense of responsibility and empowerment. Soldiers, civilians, media commentators, politicians, all begin to lose their ethical moorings. We can surely see that it will be hard for any Iraqi - or Lebanese - mother to feel it was necessary and proportional to kill her son. 'Why', she might well demand to know, 'when America is so powerful and strong did you need to kill my husband?'

Here we can begin to see the dangers in turning the old distinction between combatants and civilians into a principle. The 'principle of distinction'. There is something oxymoronic here - it is either a distinction, or a principle. As the law in war became a matter of standards, balancing, and pragmatic calculation, the difficult, discretionary decisions were exported to the political realm. But when they get there, we find politicians seeking cover beneath the same legal formulations. Judgment, leadership, responsibility are in short supply.

There is no avoiding decisions about who to kill in warfare. The difficulty arises when humanitarian law transforms decisions about who to kill into judgments; when it encourages us to think death results, not from an exercise of human freedom, for which a moral being is responsible, but rather from the abstract operation of professional principles; or from a professional balance of competing human rights. Pretending that these decisions arise from the pragmatic assessment of competing principles can mean a loss of the experience of responsibilitycommand responsibility, ethical responsibility, political responsibility. Indeed, the greatest threat posed by the merger of law and war is loss of the human experience of moral jeopardy in the face of death, mutilation, and all the other horrors of warfare.

\section{So, what can be done?}

I certainly hope the humanitarian impulse will continue to mobilize people to become partners in rulership. My hope is for a more responsible, and more effective humanitarianism. We will need, however, to move beyond the twin dangers of an idolatry of rules and a pragmatism of principles. Ultimately, responsible rulership must be a practice of each humanitarian professional. We should encourage aspiring human rights activists to embrace the exercise of power and to develop an enhanced 
appetite for political conflict, and for the responsible exercise of human freedom - rather than the ethical self-confidence of idolatry or the evasions of instrumental reason.

We are up against some pretty daunting challenges on the global stage. Pandemics, global warming, financial instability, inequality - it is a long list. I worry that the human rights revolution may have been a delay and diversion: a status quo project of legitimation and an establishment career option for those who might otherwise have contributed to a new global politics. The global economic crisis is more than a challenge for technocrats and financial regulators. It presses upon us the limitations of a national politics in a global economy and a global society. The risks are not just those of unemployment or shrinking retirement savings. The risks are political and social - the impact of millions of individuals slipping away from their dreams. Speaking loosely, and to put it in the starkest terms, with economic globalization and the continued loss of public capacity, in twenty years large swaths of the world will have whatever social security system, whatever environmental regime, whatever labour law, whatever wage rate prevails in China. And there is the parallel challenge posed by economic failure in the developing world by the revolution of rising frustrations among the hundreds of millions of individuals who can see in, but for whom there seems no route through the screen except by way of rebellion and spectacle.

Everywhere we confront an accelerating social and economic dualism. A rumbling fault line between two global architectures, between an insider and an outsider class, between leading and lagging sectors, both within and between national economies and political units. At the top and the bottom of the economy, we have deracinated ourselves, moving ever more often across ever greater distances. In relative terms, the middle classes are the ones who have become locked to their territory. Increasingly, the relative mobility of economics and the territorial rigidity of politics have rendered each other unstable as political and economic leadership have drifted apart. The result is a mismatch between a national politics on the one hand, and a global economy and society on the other.

These are the challenges facing humanists on the international stage in the coming decades. They are challenges about which human rights has very little to say - other than that state power must continue to be civilized and legitimate. What government - what NGO, what civil society - will be able to stem the revolutionary tide of resentment and desire unleashed along the fault lines of global politics today? Against 
this backdrop, I think we can begin to see the human rights moment for what it was - a status quo project for a stable time.

Perhaps a hundred years from now human rights professionals will still invoke norms, and shame governments, and publicize victims, and litigate injuries and indignities. But politics has moved on. Human rights is no longer the way forward - it focuses too longingly on the perfection of a politics already past its prime. Like constitutional orders before it, a new global governance regime will be imagined and built through collective hope, struggle, and disappointment. It took a long time to invent and civilize a national politics, to organize the world in nation states, and to subject them to one another's ethical judgment. Building a national politics across the planet had a strong emancipatory dimension slaves, women, workers, peasants, colonial dominions obtained citizenship in relationship to the new institutional machinery of a national politics. We can see human rights as the apogee and epitaph for that politics. Building a new politics for a global society and a global economy will be every bit as difficult. Let us hope it does not take as long; and does not require as much violence in order to be born. 